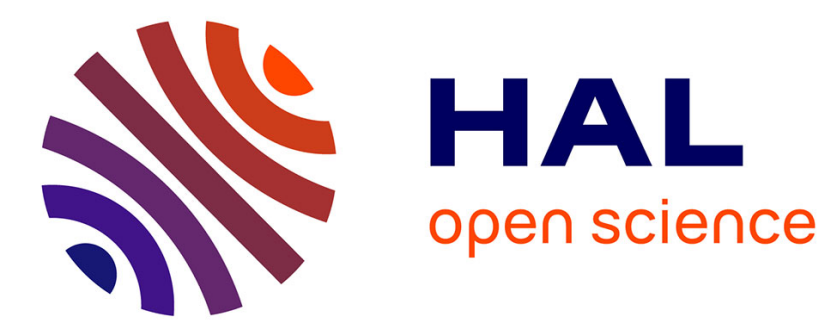

\title{
Electrochemical Dearomative Dihydroxylation and Hydroxycyclization of Indoles
}

Ju Wu, Régis Guillot, Cyrille Kouklovsky, Guillaume Vincent

\section{To cite this version:}

$\mathrm{Ju} \mathrm{Wu}$, Régis Guillot, Cyrille Kouklovsky, Guillaume Vincent. Electrochemical Dearomative Dihydroxylation and Hydroxycyclization of Indoles. Advanced Synthesis and Catalysis, 2020, 362 (8), pp.1712-1719. 10.1002/adsc.202000158 . hal-02960497

\section{HAL Id: hal-02960497 \\ https://hal.science/hal-02960497}

Submitted on 12 Nov 2020

HAL is a multi-disciplinary open access archive for the deposit and dissemination of scientific research documents, whether they are published or not. The documents may come from teaching and research institutions in France or abroad, or from public or private research centers.
L'archive ouverte pluridisciplinaire HAL, est destinée au dépôt et à la diffusion de documents scientifiques de niveau recherche, publiés ou non, émanant des établissements d'enseignement et de recherche français ou étrangers, des laboratoires publics ou privés. 
DOI: 10.1002/adsc.201((will be filled in by the editorial staff))

\title{
Electrochemical dearomative dihydroxylation and hydroxycyclization of indoles
}

\author{
$\mathrm{Ju} \mathrm{Wu},{ }^{\mathrm{a}}$ Régis Guillot, ${ }^{\mathrm{a}}$ Cyrille Kouklovsky ${ }^{\mathrm{a}}$ and Guillaume Vincent ${ }^{\mathrm{a} *}$ \\ a Université Paris-Saclay, CNRS, Institut de Chimie Moléculaire et des Matériaux d'Orsay (ICMMO), 91405, Orsay, \\ France. \\ guillaume.vincent@universite-paris-saclay.fr
}

Received: ((will be filled in by the editorial staff))

Supporting information for this article is available on the WWW under http://dx.doi.org/10.1002/adsc.201\#\#\#\#\#.

\begin{abstract}
We describe a simple and sustainable $\mathrm{MgBr}_{2}-$ mediated electrochemical dearomative dihydroxylation and hydroxycyclization reactions of indoles with water. $\mathrm{MgBr}_{2}$ is used in substoichiometric amount and acts as an electrolyte and potentially as a redox mediator to indirectly oxidize the indole nucleus into a bromonium ion which is involved in the aforementioned reactions.
\end{abstract}

Keywords: Electrochemistry; Indole; Dearomatization; Dihydroxylation; Electrocatalyst

In the last decade, the resurgence of electrochemistry ${ }^{[1]}$ contributed to an upsurge of oxidative vicinal difunctionalization methods of alkenes in sustainable conditions. ${ }^{[2]}$ The related electrochemical dearomative 1,2-difunctionalization of (hetero)arenes and in particular indoles has been less studied. ${ }^{[3-8]}$ The dearomatization of indole, for which we have been interested for almost a decade, ${ }^{[9,10]}$ generates three dimensional indolines of potential biological relevance. ${ }^{[11]}$ In few cases, dearomative electrolysis could be performed from an N-H indole substrate $^{[6]}$ as it was demonstrated by Harran during the 60 gram-scale synthesis of the benzofuroindoline core of DZ-2384, a highly potent antitumoral agent inspired by the natural product diazonamide A. ${ }^{[6]}$ However, most electrochemical methods to achieve this transformation rely on the generation of a radical cation $\mathbf{A}$ via the direct anodic oxidation of the indole nucleus $\mathbf{1}$ bearing an electron-withdrawing group on the nitrogen to deliver indolines $2 .{ }^{[7,8]}$ According to this concept, Royer reported, in 2004, one example of the dearomative dimethoxylation of a $\beta$ tetrahydrocarboline. ${ }^{[7 \mathrm{a}]}$ One example of the dimethoxylation of the 2,3-unsubstituted N-Ts indole was latter reported by Zhang and $\mathrm{Xu}$. ${ }^{[7 \mathrm{~d}]}$ The 2,3difluorination of indoles was described by Fuchigami in 2010. ${ }^{[7 \mathrm{~b}]}$ More recently, Lei implemented in electrochemical conditions the oxidative coupling between $\mathrm{N}-\mathrm{Ac}$ indoles and phenols ${ }^{[7 \mathrm{c}]}$ that we previously described in presence of $\mathrm{FeCl}_{3}$ and DDQ. ${ }^{[10 \mathrm{~b}]}$ It should also be noted that, Lin reported one example of the diazidation of N-Ts indole via the formation of a $\mathrm{N}_{3}-[\mathrm{Mn}]$ intermediate which adds onto the indole nucleus. ${ }^{[5 a]}$
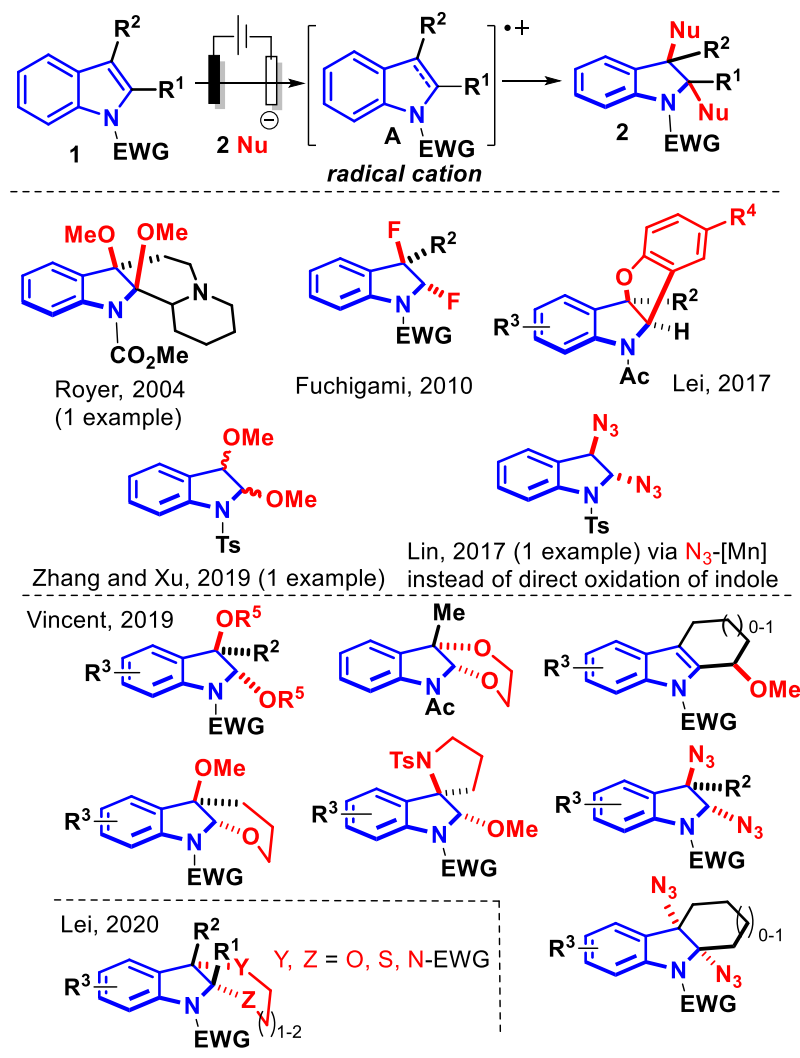

Scheme 1. Direct electrochemical dearomatization of NEWG indoles.

In this context, we recently published a general dearomative difunctionalization of indoles $\mathrm{N}$ substituted by an electron-withdrawing group in galvanostatic conditions (Scheme 1) ${ }^{[8]}$ In presence of alcohols, including ethylene glycol, 2,3-dialkoxylation occurred. In the case of 2,3-substituted indoles, the dimethoxylated indolines spontaneously evolved into $\alpha$-methoxyindoles via elimination of methanol. In presence of an oxygenated or nitrogenated nucleophile 
on the C3-substituent with a three carbon-linker, methoxycyclization was observed. Finally, the use of TMS azide as nucleophile resulted in the dearomative 2,3-diazidation of indoles. Few months later, Lei described electrochemical dearomative annulation reactions of indoles with diols and other $\mathrm{O}, \mathrm{N}$ or $\mathrm{S}$ containing bisnucleophiles. ${ }^{[7 \mathrm{e}]}$

In contrast to the direct anodic oxidation of the indole nucleus, we very recently performed an indirect electrochemical dearomatization of indole derivatives (Scheme 2). Recognising that, like several other arenes and unsaturated substrates, ${ }^{[12]} 3$-unsubsituted indoles $\mathbf{3}$ could be halogenated into 4 or 5 by electrolysis in presence of halides, ${ }^{[13]}$ we achieved the $\mathrm{MgBr}_{2}-$ mediated conversion of tryptophol, tryptamine and tryptophan derivatives $\mathbf{6}$ into bromofuranoindolines and bromopyrroloindolines 7 without the need of an additional electrolyte. ${ }^{[14]}$ In this process, $\mathrm{MgBr}_{2}$ is presumably oxidized at the anode into an electrophilic bromine reagent which could react with the indole nucleus to form bromonium ion $\mathbf{B}$ which is then intramolecularly intercepted by the oxygen or nitrogen nucleophile on the C3-substituent to deliver 7. A parallel could be drawn with the work of Tong who performed a similar process via the in-situ oxidation of halides with oxone in order to limit the generation of organic by-products or the use of toxic reagents. ${ }^{[15]}$
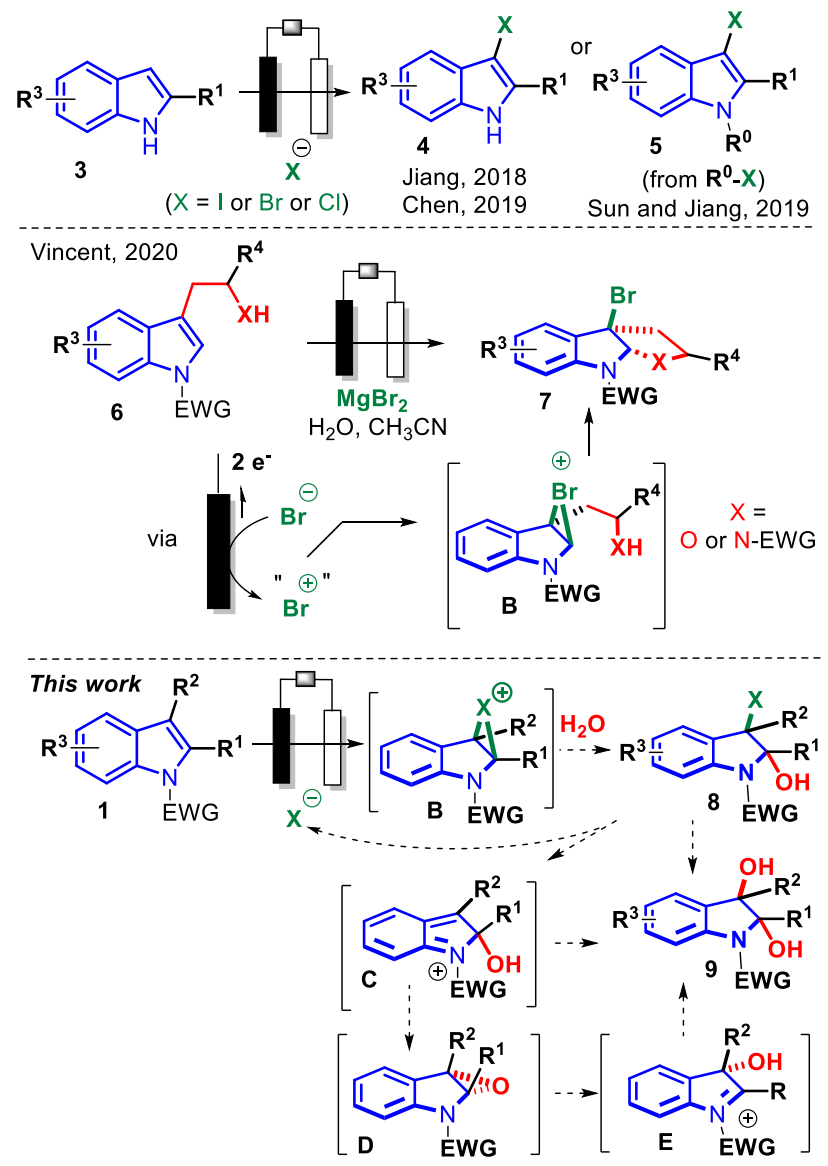

Scheme 2. Halide-mediated electrochemical dearomatization of indoles.
The purpose of the present report is to study the reactivity of other indole substrates without a pendant nucleophilic entity at the C3-position in electrochemical conditions with halide salts. We wandered if, in presence of a nucleophile such as water, the halonium ion $\mathbf{B}$ would delivered 2-hydroxy,3haloindoline 8. Alternatively, the halide of the latter could be displaced by a second molecule of water by direct $\mathrm{SN}_{2}$ or via extended imminium $\mathbf{C}$ or via epoxide $\mathbf{D}$ and 3-hydroxyindolenium $\mathbf{E}$ in order to form the dihydroxylindoline 9. In this case, the bromide ion would be regenerated and could act as a redox mediator in sub-stoichiometric amounts. It should be noted that halides are known electrocatalysts in the context of oxidative coupling reactions. ${ }^{[16]}$

Consequently, we started to study the electrochemical dearomatization of N-Ts indole 1a in water as a co-solvent with acetonitrile in an undivided cell with a graphite anode and a platinum cathode (Table 1).

Table 1. Optimization of the electrochemical dihydroxylation of 1a.
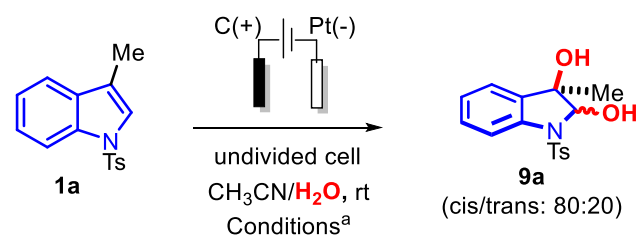

\begin{tabular}{lllll}
\hline Entry & $\begin{array}{l}\text { Additive } \\
\text { (equiv.) }\end{array}$ & $\begin{array}{l}\text { Current } \\
\text { and cell } \\
\text { potential }\end{array}$ & $\begin{array}{l}\mathrm{CH}_{3} \mathrm{CN} / \\
\mathrm{H}_{2} \mathrm{O}\end{array}$ & $\begin{array}{l}\text { Yield } \\
\mathbf{9 a}^{\mathrm{c}}\end{array}$ \\
\hline 1 & $\mathrm{Bu}_{4} \mathrm{NBF}_{4}(1)$ & $9 \mathrm{~mA} / \mathrm{cm}^{2}$ & $4 / 1$ & $49 \%$ \\
2 & $\mathrm{Bu}_{4} \mathrm{NBF}_{4}(1)$ & $9 \mathrm{~mA} / \mathrm{cm}^{2}$ & $3 / 2$ & $50 \%$ \\
3 & $\mathrm{MgCl}_{2}(1)$ & $9 \mathrm{~mA} / \mathrm{cm}^{2}$ & $4 / 1$ & $34 \%$ \\
4 & $\mathrm{NaCl}(1)$ & $9 \mathrm{~mA} / \mathrm{cm}^{2}$ & $4 / 1$ & $28 \%$ \\
5 & $\mathrm{MgBr}(1)$ & $9 \mathrm{~mA} / \mathrm{cm}^{2}$ & $4 / 1$ & $47 \%$ \\
6 & $\mathrm{NaBr}(1)$ & $9 \mathrm{~mA} / \mathrm{cm}^{2}$ & $4 / 1$ & $33 \%$ \\
7 & $\mathrm{KBr}^{2}(1)$ & $9 \mathrm{~mA} / \mathrm{cm}^{2}$ & $4 / 1$ & $34 \%$ \\
8 & $\mathrm{Bu}_{4} \mathrm{NBr}^{2}(1)$ & $9 \mathrm{~mA} / \mathrm{cm}^{2}$ & $4 / 1$ & $11 \%$ \\
9 & $\mathrm{MgI}_{2}(1)$ & $9 \mathrm{~mA} / \mathrm{cm}^{2}$ & $4 / 1$ & $\mathrm{NR}$ \\
10 & $\mathrm{NaI}^{2}(1)$ & $9 \mathrm{~mA} / \mathrm{cm}^{2}$ & $4 / 1$ & $\mathrm{NR}$ \\
11 & $\mathrm{MgBr}_{2}(0.25)$ & $9 \mathrm{~mA} / \mathrm{cm}^{2}$ & $4 / 1$ & $60 \%$ \\
12 & $\mathrm{MgBr}_{2}(0.25)$ & $4.5 \mathrm{~V}$ & $4 / 1$ & $60 \%$ \\
13 & $\mathrm{MgBr}_{2}(0.25)$ & $5 \mathrm{~V}$ & $4 / 1$ & $71 \%$ \\
14 & $\mathrm{MgBr}_{2}(0.25)$ & $6 \mathrm{~V}$ & $4 / 1$ & $64 \%$ \\
15 & $\mathrm{MgBr}_{2}(0.25)$ & $5 \mathrm{~V}$ & $3 / 2$ & $74 \%$ \\
\hline
\end{tabular}

a) Undivided cell, graphite-SK50 anode $(1.4 \mathrm{~cm} \mathrm{x} 0.8 \mathrm{~cm} \mathrm{x}$ $0.2 \mathrm{~cm}$ submerged), platinum plated cathode $(1.4 \mathrm{~cm} \times 0.8$ $\mathrm{cm} \times 0.2 \mathrm{~cm}$ submerged $), 1 \mathrm{a}(0.2 \mathrm{mmol})$, additive, $5 \mathrm{~mL}$ of $\mathrm{CH}_{3} \mathrm{CN} / \mathrm{H}_{2} \mathrm{O}$, room temperature; b) between the two electrodes; ${ }^{\text {c) }}$ Isolated yield.

In our previous reported conditions of direct anodic oxidation of $1 \mathrm{a}$ at a constant current of $9 \mathrm{~mA} . \mathrm{cm}^{-1}$ with $\mathrm{nBu}_{4} \mathrm{NBF}_{4}$ as electrolyte, dihydroxyindoline 9a was obtained in a moderate yield (entries 1,2). ${ }^{[17]}$ Replacing the electrolyte by a halide salt also delivered dihydroxyindoline $9 \mathbf{a}$ without the observation of 2- 
hydroxy-3-haloindoline 8a (entries 3-8). Among the chlorides (entries 3,4), bromides (entries 4-8) and iodides (entries 9,10) which were evaluated, $\mathrm{MgBr}_{2}$ proved to be the more promising redox mediator (entry 5). We observed the bromination of the benzene ring of $9 \mathbf{a}$ as a side reaction. Therefore, decreasing the load of $\mathrm{MgBr}_{2}$ from one equivalent to 0.25 equivalent led to an increase of the yield to $60 \%$ (entry 11). Conducting, the electrolysis in potentiostatic conditions (entries 12-14) instead of galvanostatic conditions led to an improved yield (71\%) at a constant potential of $5 \mathrm{~V}$ between the two electrodes (entry 13). Finally, a slight increase of the yield to $74 \%$ could be obtained, as a 4:1 diastereoisomeric ratio in favour of the cis diastereoisomer, with a higher concentration of water (entry 15). Very usefully, in addition to potentially be a redox mediator, $\mathrm{MgBr}_{2}$ also acts as an electrolyte.

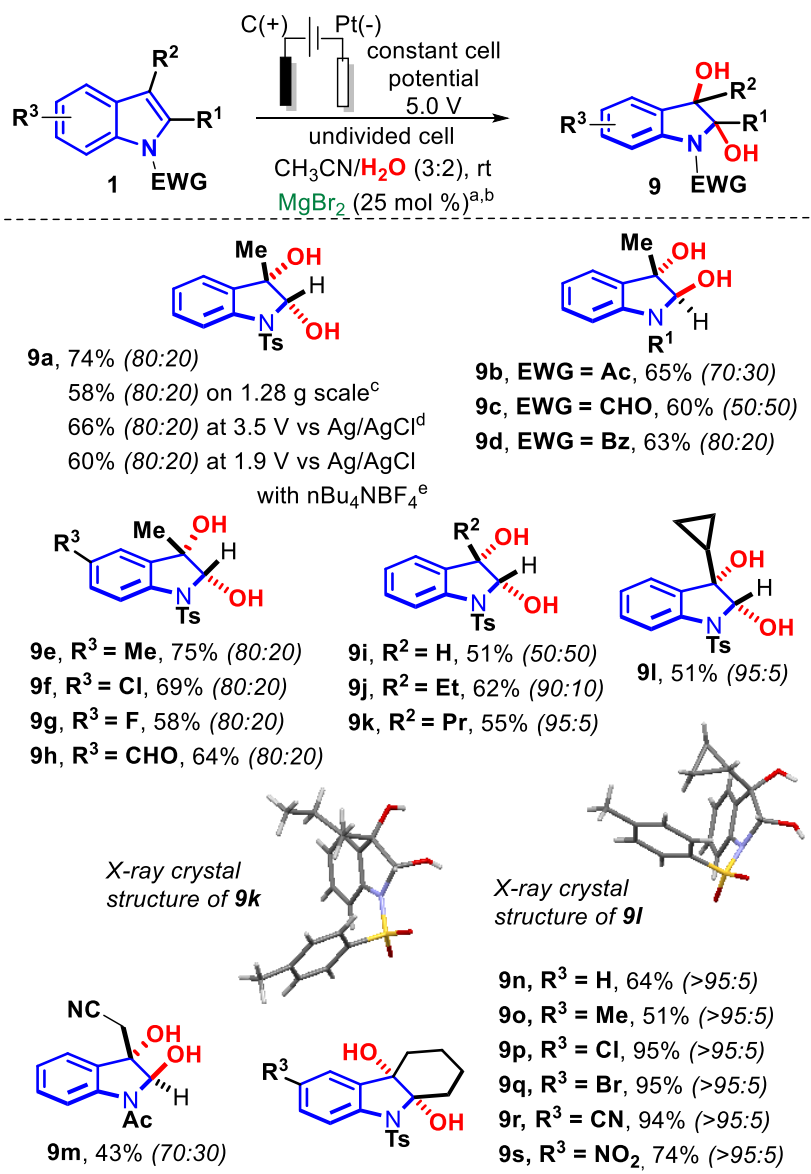

Scheme 3. $\mathrm{MgBr}_{2}$-mediated electrochemical dearomative dihydroxylation of indoles. ${ }^{\text {a) }}$ Undivided cell, graphite-SK50 anode $(1.4 \mathrm{~cm} \times 0.8 \mathrm{~cm} \times 0.2 \mathrm{~cm}$ submerged), platinum plated cathode $(1.4 \mathrm{~cm} \times 0.8 \mathrm{~cm} \times 0.2 \mathrm{~cm}$ submerged), constant potential of $5 \mathrm{~V}$ between the electrodes, $1(0.2$ $\mathrm{mmol}$ ), $\mathrm{MgBr}_{2}$ (0.05 mmol), $\mathrm{CH}_{3} \mathrm{CN} / \mathrm{H}_{2} \mathrm{O}(3 \mathrm{~mL} / 2 \mathrm{~mL})$, room temperature; ${ }^{\mathrm{b})}$ isolated yields (diastereomeric ratio of the major isomer as drawn) are indicated; ${ }^{\mathrm{c})}$ anode $(3.4 \mathrm{~cm} \mathrm{x}$ $0.8 \mathrm{~cm}$ x $0.2 \mathrm{~cm}$ submerged), cathode ( $3.4 \mathrm{~cm} \times 0.8 \mathrm{~cm} \times 0.2$ $\mathrm{cm}$ submerged), 1 (4.5 mmol), $\mathrm{MgBr}_{2}$ (1.125 mmol), $\mathrm{CH}_{3} \mathrm{CN} / \mathrm{H}_{2} \mathrm{O}(10 \mathrm{~mL} / 6 \mathrm{~mL})$; ${ }^{\mathrm{d})}$ constant potential of $3.5 \mathrm{~V}$ at the anode $v s$ an $\mathrm{Ag} / \mathrm{AgCl}(3 \mathrm{M}$ aq. $\mathrm{KCl})$ ref electrode; e) constant potential of $1.9 \mathrm{~V}$ at the anode $v s$ an $\mathrm{Ag} / \mathrm{AgCl}(3 \mathrm{M}$ aq. $\mathrm{KCl})$ ref electrode when $\mathrm{nBu}_{4} \mathrm{NBF}_{4}(0.2 \mathrm{mmol})$ was added to the reaction mixture.

The synthesis of 9a could be conducted on a gram scale (Scheme 3). We also performed successfully the electrolysis with a constant potential of $3.5 \mathrm{~V}$ at the anode $v s$ an $\mathrm{Ag} / \mathrm{AgCl}$ reference electrode. In this case, $3.5 \mathrm{~V}$ is unlikely the anode potential due to the probable high resistance of the reaction mixture. Therefore, to decrease the resistance of the solution, $\mathrm{nBu}_{4} \mathrm{NBF}_{4}$ was added as an additional supporting electrolyte and a $60 \%$ yield of $9 \mathrm{a}$ was obtained at 1.9 $\mathrm{V} v s \mathrm{Ag} / \mathrm{AgCl}$ with 0.25 equiv. of $\mathrm{MgBr}_{2}$.

Subsequently, we studied the scope of this $\mathrm{MgBr}_{2}-$ mediated electrochemical dihydroxylation reaction at a constant cell potential of $5 \mathrm{~V}$ in order to have a simple reaction set-up (Scheme 3). Switching the tosyl group born by the nitrogen of the indole to acyl groups such as acetyl, formyl and benzoyl yielded indolines $9 \mathbf{b - d}$ but with the trans isomer as the major product. ${ }^{[17 \mathrm{~d}]}$ The diastereoselectivity of this dihydroxylation of indoles appears to be controlled by the indolic nitrogen substituent. At this point, we decided to continue our investigation with a tosyl as the electron-withdrawing group on the nitrogen in most cases. ${ }^{[18]}$ The substitution on the benzene part of the indole proved to be tolerant to both electron-donating groups, halogens and electron-withdrawing groups with the formation of indolines $\mathbf{9 e - h}$ with the cis isomer as the major compound. A sensitive aldehyde is compatible in these conditions as demonstrated by the synthesis of dihydroxyindoline 9h. 2,3-Unsubstituted-N-Ts-indole was also a competent substrate which delivered indoline 9i. The cis-dearomative dihydroxylation of $\mathrm{N}-\mathrm{Ts}$ indoles proceeded well with various substituents at the C3-position such as alkyl groups $(\mathbf{9 j - 1}) \cdot{ }^{[19]} 3$ Cyclopropyl-indoline 91 was obtained with only minor amounts of the opening of the cyclopropyl ring. ${ }^{[19]} \mathrm{A}$ nitrile could also be present on the C3-alkyl side chain to deliver 9m without hydrolysis. We were also interested by the behaviour of tetrahydrocarbazoles in these reaction conditions. We were pleased to observe the formation of the cis-2,3-dihydroxyindolines 9n-s which contain either electron-donating $(\mathbf{9 o})$, halogens $(\mathbf{9 p}, \mathbf{q})$ or electron-withdrawing $(\mathbf{9 r}, \mathbf{s})$ substituents. This result is in contrast with our previous direct methoxylation conditions in which $\alpha$-methoxy tetrahydrocarbolines were obtained instead of the desired 2,3-dimethoxyindolines (Scheme 1). ${ }^{[8]}$ It proves that the $\mathrm{MgBr}_{2}$-mediated conditions are milder than our previous ones since 9n-s did not evolve into $\alpha$-hydroxyl tetrahydrocarbolines.

We then turned our attention towards substrates that contain a nucleophilic entity on a three carbon-side chain born by the C3-position of $\mathbf{1 0}$ and $\mathbf{1 1}$ (Scheme 4). We expected to observe a bromocyclization as in the cases of tryptophol tryptamine and tryptophan derivatives 6 which yielded 7 (Scheme 2). However, the addition of one carbon to the linker between the indole and the nucleophile led to a different outcome. 
In the case of oxygenated nucleophiles, the $\mathrm{C} 2$ position of the oxidized indole is intramolecularly intercepted by this nucleophile, while the $\mathrm{C} 3$-position is attacked by water. ${ }^{[20]}$ Hydroxytetrahydropyranoindolines 12a-d were thus obtained from indoles containing a primary or a tertiary alcohol. Replacing the alcohol by a carboxylic acid led to the corresponding $\delta$-valerolactones 12e,f. In contrast, the regioselectivity was inverted with a nitrogenated intramolecular nucleophile, since 2-hydroxy-3,3spiroindolines 13a-c were obtained via intramolecular attacked of the sulfonamide at the C3-position of the indole. ${ }^{[19,21]}$
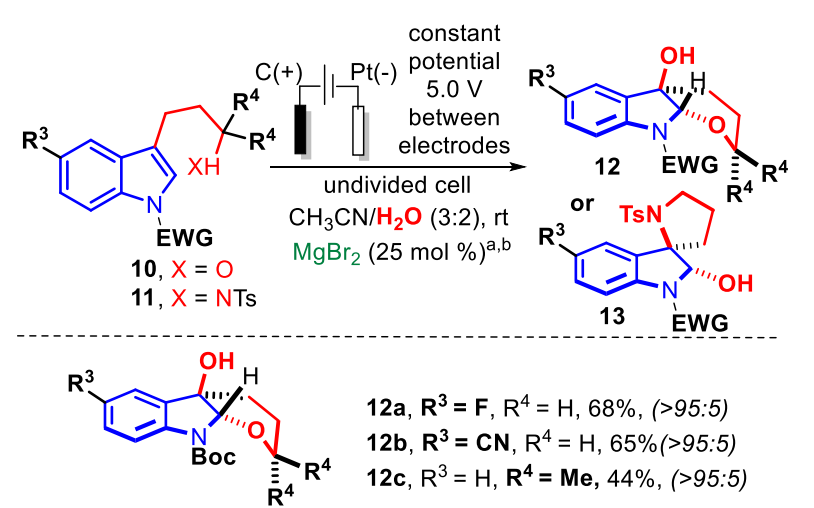

12a, $\mathbf{R}^{3}=\mathbf{F}, \mathrm{R}^{4}=\mathrm{H}, 68 \%,(>95: 5)$

12b, $\mathbf{R}^{3}=\mathbf{C N}, \mathrm{R}^{4}=\mathrm{H}, 65 \%(>95: 5)$

12c, $R^{3}=H, R^{4}=\mathbf{M e}, 44 \%,(>95: 5)$

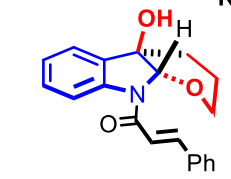

12d, $47 \%$, (>95:5)

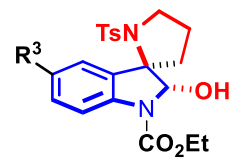

13a, $\mathbf{R}^{5}=$ OMe, $47 \%(>95: 5)$

13b, $\mathbf{R}^{5}=\mathbf{M e}, 59 \%(>95: 5)$

13c, $\mathbf{R}^{5}=\mathbf{F}, 36 \%(>95: 5)$

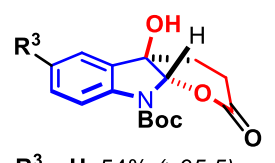

12e, $\mathbf{R}^{3}=\mathbf{H}, 54 \%(>95: 5)$

12f, $\mathbf{R}^{3}=\mathbf{M e}, 47 \%(>95: 5)$

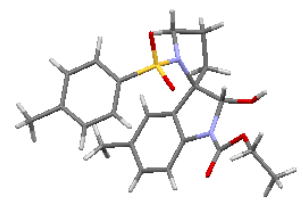

$X$-ray crystal structure of $13 b$

Scheme 4. $\mathrm{MgBr}_{2}$-mediated electrochemical dearomative hydroxycyclization of indole derivatives. ${ }^{\text {a) }}$ Undivided cell, graphite-SK50 anode ( $1.4 \mathrm{~cm} \times 0.8 \mathrm{~cm} \times 0.2 \mathrm{~cm}$ submerged), platinum plated cathode $(1.4 \mathrm{~cm} \times 0.8 \mathrm{~cm} \times 0.2 \mathrm{~cm}$ submerged), constant potential of $5 \mathrm{~V}$ between the electrodes, 10 or $11(0.2 \mathrm{mmol}), \mathrm{MgBr}_{2}(0.05 \mathrm{mmol})$, $\mathrm{CH}_{3} \mathrm{CN} / \mathrm{H}_{2} \mathrm{O}(3 \mathrm{~mL} / 2 \mathrm{~mL})$, room temperature; $\left.{ }^{b}\right)$ isolated yields (diastereomeric ratio of the major isomer as drawn) are indicated.

In order to have a better understanding of these oxidative dearomatizations of $\mathrm{N}$-substituted indoles, cyclic voltammetry (CV) of the reactants in acetonitrile and water were recorded (Figure 1). Similarly, to our bromocyclization of tryptophol and tryptamine derivatives $\mathbf{6}, \mathrm{N}$-Ts skatole $\mathbf{1 a}$ is oxidized at a higher potential than $\mathrm{MgBr}_{2} \cdot{ }^{[12 j, 22]}$ Moreover, the $\mathrm{CV}$ of a mixture of $\mathrm{N}-\mathrm{Ts}$ skatole $\mathbf{1 a}$ and $\mathrm{MgBr}_{2}$ shows an increase of the current intensity of the oxidation peak of $\mathrm{MgBr}_{2}$ into presumably $\mathrm{Br}_{2}$. It is an argument

for the selective oxidation of $\mathrm{MgBr}_{2}$ into an electrophilic bromine intermediate.

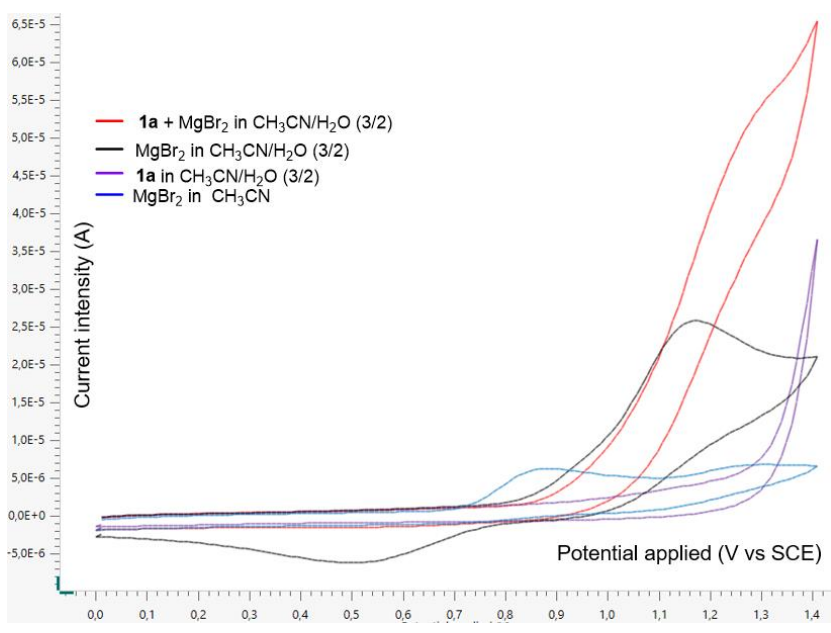

Figure 1. Cyclic voltammograms of reactants in a mixture of acetonitrile and water. A glassy carbon disc (diameter 3 $\mathrm{mm}$ ) working electrode, a platinum wire counter electrode and a saturated calomel electrode (SCE) as reference electrode were used at a scan rate of $100 \mathrm{mV} / \mathrm{s} ; 0.05 \mathrm{mmol}$ 1a and/or $0.025 \mathrm{mmol} \mathrm{MgBr}_{2}, 1 \mathrm{mmol} \mathrm{nBu}_{4} \mathrm{NBF}_{4}$ in $10 \mathrm{~mL}$ of $\mathrm{CH}_{3} \mathrm{CN} / \mathrm{H}_{2} \mathrm{O}(3: 2)$ or $\mathrm{CH}_{3} \mathrm{CN}$.

We then performed control experiments to get additional insights whether this reaction could proceed via the formation of bromonium intermediate $\mathbf{B}$ from electrogenerated $\mathrm{Br}_{2}$ or via direct oxidation of the indole into radical cation $\mathbf{A}$ (Scheme 5).

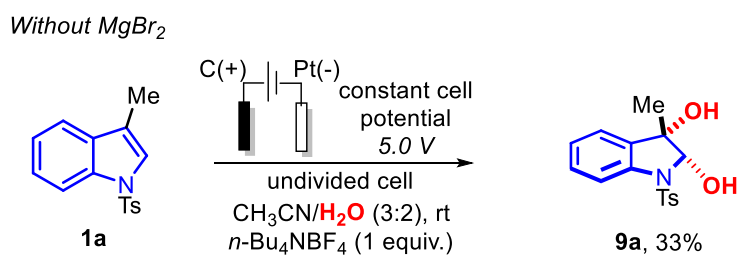

With an electrophilic-bromine reagent in non-electrochemical conditions

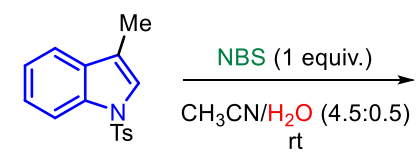

1a<smiles>O=C(O)c1ccc2c(c1)CCCCO2</smiles>

$10 \mathrm{a}$
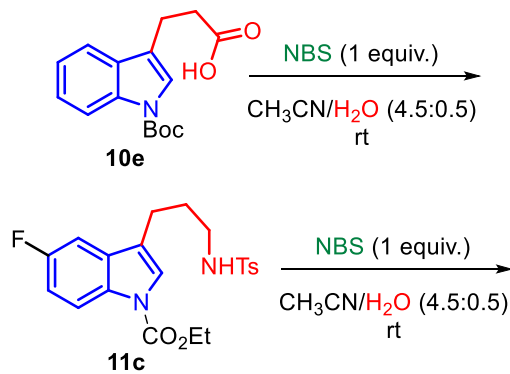

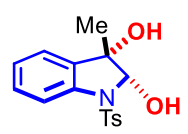

$9 a, 83 \%$<smiles>O=[13C]1C2=CC=CC2=C(O)c2cc(F)ccc21</smiles>

12a, $19 \%$
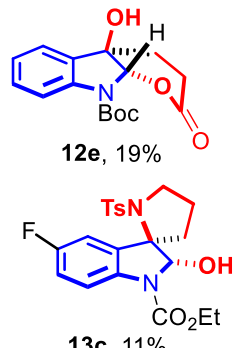

13c. $11 \%$ 
Scheme 5. Control experiments.

Removing $\mathrm{MgBr}_{2}$ and using $n \mathrm{Bu}_{4} \mathrm{NBF}_{4}$ as electrolyte with a $5 \mathrm{~V}$ cell potential led to a significant decrease of the yield of $9 \mathbf{a}$ from $74 \%$ (Scheme 2) to $33 \%$ (Scheme 4). The reaction is sluggish and the formation of several by-products was observed. The fact that 9a could be obtained without $\mathrm{MgBr}_{2}$ proves that the dihydroxylation could be performed by a direct oxidation of NTs-skatole 1a at the anode into a radical cation $\mathbf{A}$. However, this process is significantly less efficient in comparison to the use of $\mathrm{MgBr}_{2}$. It may indicate that in the presence of $\mathrm{MgBr}_{2}$, the major pathway involves the anodic formation of an electrophilic bromine reagent such as $\mathrm{Br}_{2}$ followed by formation of bromonium ion B. Avoiding the direct oxidation of 1a at the anode seems to allow a better chemoselectivity.

To prove that an ephemeral electrophilic bromine reagent could be involved in the dihydroxylation and hydroxycyclisation reactions, the reaction of 1a, 10a, 10e and 11c with NBS as an electrophilic bromine reagent in non-electrochemical conditions led to the formation of 9a, 12a, 12e and 13c albeit in a significantly lower yield in the three last cases. It tends to confirm that in our electrochemical conditions $9 \mathbf{a}$ could be generated from bromonium ion $\mathbf{B}$.

In our recent electrochemical bromocyclization of $\mathbf{6}$ into bromofuranoindolines and bromopyrroloindolines $\mathbf{7}$ which were conducted in the same conditions, it seems obvious that electrogenerated $\mathrm{Br}_{2}$ reacts with $\mathbf{6}$ to form bromonium bridge $\mathbf{B}$ which is then intramolecularly opened to deliver 7. ${ }^{[13]}$ It is in itself a clue that, in these reported conditions with $\mathrm{MgBr}_{2}$, 1a could electrochemically be converted into $\mathbf{B}$ which could then lead to 9a upon reaction with water.

Our mechanistic hypothesis could be summarized in Scheme 6. In all cases, we believe that the major pathway involves the two electrons anodic oxidation of two bromides into one bromine which could react with the $\mathrm{C} 2=\mathrm{C} 3$ bond of the indole nucleus to deliver bromonium ion $\mathbf{B}$. The direct oxidation of indole $\mathbf{1}$ into a radical cation $\mathbf{A}$ could not be ruled out and may also co-exists as a minor pathway. Addition to $\mathbf{B}$ of hydroxide ions, which would have been formed via reduction of water at the cathode, could then lead to dihydroxyindoline $\mathbf{9}$ via intermediates $\mathbf{C}, \mathbf{D}$ or $\mathbf{E}$ as depicted in Scheme 1. The cis/trans ratio observed for 9 is probably the result of a thermodynamic equilibrium via epimerisation at the $\mathrm{C} 2$-position through formation of ketone intermediate $\mathbf{F}$, as it was previously observed. ${ }^{[17 \mathrm{~d}]}$ The reason why the cis isomer in the case of a Ts group and the trans isomer in the case of an acyl group are respectively preferred are not clear to us. ${ }^{[23]}$ Intramolecular opening of $\mathbf{B}$ is also possible in presence of a nucleophilic entity in the $\mathrm{C} 3$-position of the indole nucleus which would deliver brominated tricyclic compounds $\mathbf{G}$ and $\mathbf{7}$. The former could then be converted to hydroxypyranoindoline $\mathbf{1 2}$ probably via extended iminium $\mathbf{H}$. In the latter case, bromofuranoindolines and bromopyrroloindolines 7 are stable and could be isolated since the formation of the corresponding iminium H' would be less favoured due to its ring strain.

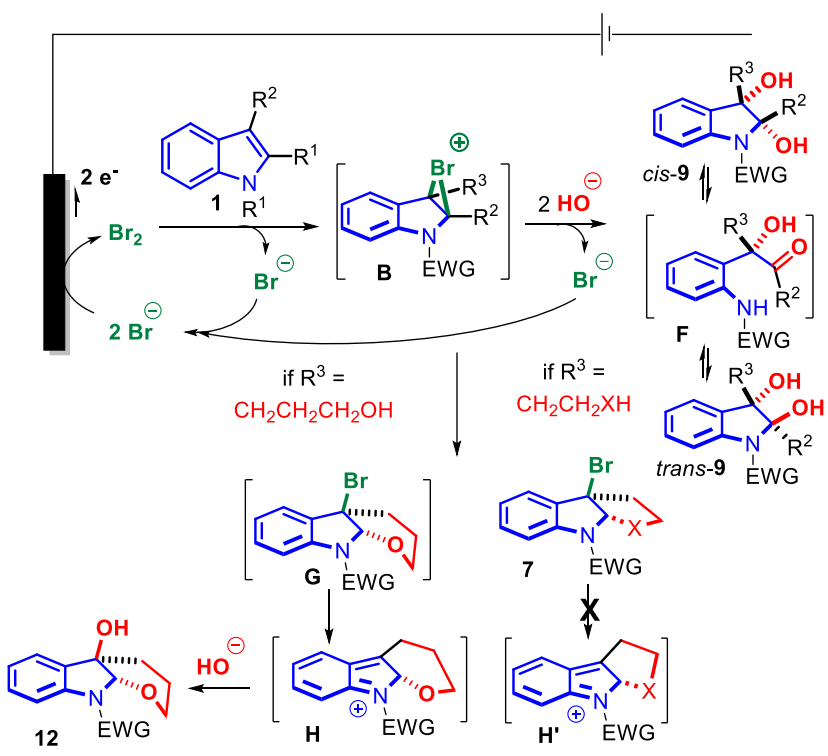

Scheme 6. Mechanistic hypothesis.

In summary, a simple electrochemical protocol to perform the dearomative dihydroxylation and hydroxycyclisation of indoles in presence of $\mathrm{MgBr}_{2}$ without the need of an additional electrolyte has been described. We postulate that the major pathway involves the electrochemical generation of an electrophilic bromine reagent from $\mathrm{MgBr}_{2}$ which could lead to oxidation of the indole into a bromonium ion. Upon reaction with water, this intermediate is transformed into 2,3-dihydroxyindolines. In presence of an intramolecular nucleophile and water, hydroxycyclization occurs leading to hydroxytetrahydropyranoindolines or 2-hydroxy-3,3spiroindolines.

\section{Experimental Section}

Electrochemical reactions were performed with ElectraSvn 2.0 package (IKA) using the constant voltage mode. To a 10 $\mathrm{mL}$ vial with a stir bar were successively added the substituted indole 2 or $\mathbf{4}(0.2 \mathrm{mmol}), \mathrm{MgBr}_{2}(0.05 \mathrm{mmol}$, 0.25 equiv), $2.0 \mathrm{~mL}$ of distilled $\mathrm{H}_{2} \mathrm{O}$ and $3.0 \mathrm{~mL}$ of $\mathrm{CH}_{3} \mathrm{CN}$ $(0.04 \mathrm{M})$, The vial was covered with a screw-cap. The electrolysis was carried out at RT using a constant voltage of $5 \mathrm{~V}$ between a graphite anode and a platinum plate cathode $(1.4 \times 0.8 \times 0.2 \mathrm{~cm}$ submerged in solution for each electrodes and a distance of $0.6 \mathrm{~cm}$ between the two electrodes $)$ with stirring $(500 \mathrm{rpm})$. The complete consumption of the starting indole derivative was checked by TLC (35\% to $50 \%$ AcOEt/petroleum ether). The reaction was then quenched with $\mathrm{H}_{2} \mathrm{O}$ and diluted with AcOEt. The organic and aqueous phases were separated. The aqueous phase was then extracted twice with AcOEt. The combined organic phases were then dried over $\mathrm{MgSO}_{4}$, filtered and concentrated under vacuum. The crude was then purified by flash column chromatography or preparative TLC (35\% to 
$50 \%$ AcOEt/ netroleum ether). Note: Most of the dihvdroxvindolines are obtained as a mixture of trans and cis diastereoisomers. The ${ }^{13} \mathrm{C}$ NMR signals of $\mathrm{C} 2$ and $\mathrm{C} 3$ are deshielded (downfield) of annroximatelv $5 \mathrm{nnm}$ for the trans isomer in comnarison to the cis isomer. The ${ }^{1} \mathrm{H}$ NMR signal of the proton at $\mathrm{C} 2$ is deshielded (downfield) of annroximatelv $0.2 \mathrm{ppm}$ for the trans isomer in comparison to the $c i s$ isomer.

\section{Acknowledgements}

We thank Mrs Sakna Bazzi and Dr. Mohamed Mellah (ICMMO, Univ. Paris Sud) for their assistance in the recording of the CV and for helpful discussions. JW thanks the China Scholarship Council (CSC) for his PhD fellowship. We also gratefully acknowledge the ANR (ANR-17-CE07-0050; "ArDCo"), the Université Paris Sud and the CNRS for financial support.

\section{References}

[1] For reviews: a) R. Francke, R. D. Little, Chem. Soc. Rev. 2014, 43, 2492-2521; b) E. J. Horn, B. R. Rosen, P. S. Baran, ACS Cent. Sci. 2016, 2, 302-308; c) M. Yan, Y. Kawamata, P. S. Baran, Chem. Rev. 2017, 117, 1323013319; d) A. Wiebe, T. Gieshoff, S. Möhle, E. Rodrigo, M. Zirbes, S. R. Waldvogel, Angew. Chem. Int. Ed. 2018 , 57, 5594-5619; e) S. Möhle, M. Zirbes, E. Rodrigo, T. Gieshoff, A. Wiebe, S. R. Waldvogel, Angew. Chem. Int. Ed. 2018, 57, 6018-6041; f) Y. Jiang, K. Xu, C. Zeng, Chem. Rev. 2018, 118, 4485-4540.

[2] For reviews: a) G. M. Martins, B. Shirinfar, T. Hardwick, N. Ahmed, ChemElectroChem 2019, 6, 1254-1254; b) G. S. Sauer, S. Lin, ACS Catal. 2018, 8, 5175-5187; c) R. Feng, J. A. Smith, K. D. Moeller, Acc. Chem. Res. 2017, 50, 2346-2352; d) K. D. Moeller, Synlett 2009, 2009, 1208-1218; for selected examples: e) K. D. Moeller, M. R. Marzabadi, D. G. New, M. Y. Chiang, S. Keith, J. Am. Chem. Soc. 1990, 112, 61236124; f) K. Fujimoto, Y. Tokuda, Y. Matsubara, H. Maekawa, T. Mizuno, I. Nishiguchi, Tetrahedron Lett. 1995, 36, 7483-7486; g) K. Chiba, M. Fukuda, S. Kim, Y. Kitano, M. Tada, J. Org. Chem. 1999, 64, 76547656; h) Y. Ashikari, T. Nokami, J. Yoshida, J. Am. Chem. Soc. 2011, 133, 11840-11843; i) C.-Y. Cai, H.-C. Xu, Nat. Commun. 2018, 9, 3551; j) J. C. Siu, G. S. Sauer, A. Saha, R. L. Macey, N. Fu, T. Chauviré, K. M. Lancaster, S. Lin, J. Am. Chem. Soc. 2018, 140, 1251112520; k) P. Xiong, H. Long, J. Song, Y. Wang, J.-F. Li, H.-C. Xu, J. Am. Chem. Soc. 2018, 140, 16387-16391; 1) Y. Wang, L. Deng, H. Mei, B. Du, J. Han, Y. Pan, Green Chem. 2018, 20, 3444-3449.

[3] For recent reviews on electrochemical dearomatizations: a) S. Lv, G. Zhang, J. Chen, W. Gao, Adv. Synth. Catal. doi:10.1002/adsc.201900750; b) K. Ye, Y. Yu, J.-S. Zhong, K. Xu, Y. Yuan, Adv. Synth. Catal. doi:10.1002/adsc.201901520.

[4] For reductive electrochemical dearomatizations of indoles: N. Kise, T. Mano, T. Sakurai, Org. Lett. 2008, 10, 4617-4620.

[5]For electrochemical dearomatization of indoles via the electrochemical generation of a reagent that adds to the indole nucleus: a) N. Fu, G. S. Sauer, A. Saha, A. Loo,
S. Lin, Science 2017, 357, 575-579; b) L. Li, S. Luo, Org. Lett. 2018, 20, 1324-1327.

[6] For electrochemical dearomatization of indoles via oxidation of NH-indoles: a) N. T. Nguyen, M. Z. Wrona, G. Dryhurst, J. Electroanal. Chem. Interfacial Electrochem. 1986, 199, 101-126; b) H. Ding, P. L. DeRoy, C. Perreault, A. Larivée, A. Siddiqui, C. G. Caldwell, S. Harran, P. G. Harran, Angew. Chem. Int. Ed. 2015, 54, 4818-4822.

[7] For electrochemical dearomatization of indoles via direct anodic oxidation of N-EWG indoles into a radical cation intermediate: a) J. Royer, L. Planas, T. Martens, F. Billon-Souquet, Heterocycles 2004, 63, 765; b) B. Yin, L. Wang, S. Inagi, T. Fuchigami, Tetrahedron 2010, 66, 6820-6825; c) K. Liu, S. Tang, P. Huang, A. Lei, Nat. Commun. 2017, 8, 775; d) S. Zhang, L. Li, P. Wu, P. Gong, R. Liu, K. Xu, Adv. Synth. Catal. 2019, 361, 485-489; e) K. Liu, W. Song, Y. Deng, H. Yang, C. Song, T. Abdelilah, S. Wang, H. Cong, S. Tang, A. Lei, Nat. Commun. 2020, 11, 3.

[8] J. Wu, Y. Dou, R. Guillot, C. Kouklovsky, G. Vincent, J. Am. Chem. Soc. 2019, 141, 2832-2837.

[9] For reviews on indole dearomatization: a) S. P. Roche, J.-J. Youte Tendoung, B. Tréguier, Tetrahedron 2015, 71, 3549-3591; b) N. Denizot, T. Tomakinian, R. Beaud, C. Kouklovsky, G. Vincent, Tetrahedron Lett. 2015, 56, 4413-4429.

[10] a) R. Beaud, R. Guillot, C. Kouklovsky, G. Vincent, Angew. Chem. Int. Ed. 2012, 51, 12546-12550; b) T. Tomakinian, R. Guillot, C. Kouklovsky, G. Vincent, Angew. Chem. Int. Ed. 2014, 53, 11881-11885; c) D. Lachkar, N. Denizot, G. Bernadat, K. Ahamada, M. A. Beniddir, V. Dumontet, J.-F. Gallard, R. Guillot, K. Leblanc, E. O. N'nang, et al., Nat. Chem. 2017, 9, 793798; d) D. Ryzhakov, M. Jarret, R. Guillot, C. Kouklovsky, G. Vincent, Org. Lett. 2017, 19, 63366339; e) J. Wu, R. K. Nandi, R. Guillot, C. Kouklovsky, G. Vincent, Org. Lett. 2018, 20, 1845-1848; f) D. Ryzhakov, M. Jarret, J.-P. Baltaze, R. Guillot, C. Kouklovsky, G. Vincent, Org. Lett. 2019, 21, 49864990.

[11] F. Lovering, J. Bikker, C. Humblet, J. Med. Chem. 2009, 52, 6752-6756.

[12] For recent examples: a) N. Fu, G. S. Sauer, S. Lin, J. Am. Chem. Soc. 2017, 139, 15548-15553; b) K.-Y. Ye, G. Pombar, N. Fu, G. S. Sauer, I. Keresztes, S. Lin, J. Am. Chem. Soc. 2018, 140, 2438-2441; c) Y. Yuan, A. Yao, Y. Zheng, M. Gao, Z. Zhou, J. Qiao, J. Hu, B. Ye, J. Zhao, H. Wen, et al., iScience 2019, 12, 293-303; d) Q.-L. Yang, X.-Y. Wang, T.-L. Wang, X. Yang, D. Liu, X. Tong, X.-Y. Wu, T.-S. Mei, Org. Lett. 2019, 21 , 2645-2649; e) X. Sun, H.-X. Ma, T.-S. Mei, P. Fang, Y. Hu, Org. Lett. 2019, 21, 3167-3171; f) K. Yamamoto, K. Ishimaru, S. Mizuta, D. Minato, M. Kuriyama, O. Onomura, Synlett 2019, 30, 1204-1208; g) W. Xie, S. Ning, N. Liu, Y. Bai, S. Wang, S. Wang, L. Shi, X. Che, J. Xiang, Synlett 2019, 30, 1313-1316; h) C. Chen, J.-C. Kang, C. Mao, J.-W. Dong, Y.-Y. Xie, T.-M. Ding, Y.Q. Tu, Z.-M. Chen, S.-Y. Zhang, Green Chem. 2019, 21, 
4014-4019; i) B. D. W. Allen, M. D. Hareram, A. C. Seastram, T. McBride, T. Wirth, D. L. Browne, L. C. Morrill, Org. Lett. 2019, 21, 9241-9246; see also: j) F. Billon-Souquet, T. Martens, J. Royer, Tetrahedron 1996, 52, 15127-15136.

[13] a) L. Sun, X. Zhang, Z. Li, J. Ma, Z. Zeng, H. Jiang, Eur. J. Org. Chem. 2018, 2018, 4949-4952; b) L. Sun, X. Zhang, C. Wang, H. Teng, J. Ma, Z. Li, H. Chen, H. Jiang, Green Chem. 2019, 21, 2732-2738; c) P. Zhang, J. Chen, W. Gao, Y. Xiao, C. Liu, S. Xu, X. Yan, D. Qin, Molecules 2019, 24, 696.

[14] J. Wu, H. Abou-Hamdan, R. Guillot, C. Kouklovsky, G. Vincent, Chem. Commun. 2020, DOI 10.1039/C9CC09276E.

[15] a) J. Xu, R. Tong, Green Chem. 2017, 19, 2952-2956; b) J. Xu, L. Liang, H. Zheng, Y. R. Chi, R. Tong, Nat. Commun. 2019, 10, 4754; see also: c) D. Tu, L. Ma, X. Tong, X. Deng, C. Xia, Org. Lett. 2012, 14, 4830-4833.

[16] a) M. Okimoto, H. Yamamori, K. Ohashi, S. Nishikawa, M. Hoshi, T. Yoshida, Synlett 2012, 23, 2544-2548; b) H. Gao, Z. Zha, Z. Zhang, H. Ma, Z. Wang, Chem. Commun. 2014, 50, 5034-5036; c) S. Liang, C.-C. Zeng, X.-G. Luo, F. Ren, H.-Y. Tian, B.-G. Sun, R. D. Little, Green Chem. 2016, 18, 2222-2230; d) S. Liang, C.-C. Zeng, H.-Y. Tian, B.-G. Sun, X.-G. Luo, F. Ren, J. Org. Chem. 2016, 81, 11565-11573; e) P. Qian, J.-H. Su, Y. Wang, M. Bi, Z. Zha, Z. Wang, J. Org. Chem. 2017, 82, 6434-6440; f) S. Zhang, F. Lian, M. Xue, T. Qin, L. Li, X. Zhang, K. Xu, Org. Lett. 2017, 19, 6622-6625; g) Q.-Q. Wang, K. Xu, Y.-Y. Jiang, Y.-G. Liu, B.-G. Sun, C.-C. Zeng, Org. Lett. 2017, 19, 55175520; h) S. Zhang, L. Li, M. Xue, R. Zhang, K. Xu, C. Zeng, Org. Lett. 2018, 20, 3443-3446.

[17] For a dihydroxylation of indoles with stoichiometric oxidants: a) T. Kawasaki, C.-S. Chien, M. Sakamoto, Chem. Lett. 1983, 12, 855-858; b) D. M. Harrison, Tetrahedron Lett. 1984, 25, 6063-6064; c) C. Chien, T. Suzuki, T. Kawasaki, M. Sakamoto, Chem. Pharm. Bull. 1984, 32, 3945-3951; d) C. Chien, T. Takanami, T. Kawasaki, M. Sakamoto, Chem. Pharm. Bull. 1985, 33, 1843-1848; e) J. Ye, J. Wu, T. Lv, G. Wu, Y. Gao, H. Chen, Angew. Chem. Int. Ed. 2017, 56, 14968-14972; For other related dialkoxylation of indoles with stoichiometric oxidants: f) S. Kwon, N. Kuroki, Chem. Lett. 1980, 9, 237-238; g) S. F. Vice, G. I. Dmitrienko, Can. J. Chem. 1982, 60, 1233-1237; h) H. Takayama, K. Misawa, N. Okada, H. Ishikawa, M. Kitajima, Y. Hatori, T. Murayama, S. Wongseripipatana, K. Tashima, K. Matsumoto, et al., Org. Lett. 2006, 8, 5705-5708; i) X. Zhang, C. S. Foote, J. Org. Chem. 1993, 58, 5524-5527; j) E. Desarbre, L. Savelon, O. Cornec, J. Y. Mérour, Tetrahedron 1996, 52, 2983-2994; k) L. F. Silva Jr, M. V. Craveiro, M. T. P. Gambardella, Synthesis 2007,
3851-3857; 1) A. Karadeolian, M. A. Kerr, J. Org. Chem. 2010, 75, 6830-6841; m) Q. Liu, Q. Y. Zhao, J. Liu, P. $\mathrm{Wu}, \mathrm{H}$. Yi, A. Lei, Chem. Commun. 2012, 48, 32393241.

[18] If the indole nitrogen is not substituted by an electronwithdrawing group, decomposition is observed.

[19] CCDC 1910835 (9k), 1935676 (9l) and 1910834 (13b) contain the supplementary crystallographic data for this paper.

[20] For the synthesis of related hydroxypyranoindoline derivatives via dearomatization: a) T. Hino, H. Miura, R. Murata, M. Nakagawa, Chem. Pharm. Bull. 1978, 26, 3695-3703; b) T. P. Pathak, K. M. Gligorich, B. E. Welm, M. S. Sigman, J. Am. Chem. Soc. 2010, 132, 7870-7871; c) L. Han, W. Zhang, X.-X. Shi, S.-L. You, Adv. Synth. Catal. 2015, 357, 3064-3068; see also ref. 8 and $10 \mathrm{~d}$.

[21] For the synthesis of related 3,3-spiro-3-amino-2hydroxyindoline derivatives via dearomatization: a) $\mathrm{N}$. A. Braun, J. D. Bray, M. A. Ciufolini, Tetrahedron Lett. 1999, 40, 4985-4988; b) Y.-Q. Zhang, Y.-A. Yuan, G.S. Liu, H. Xu, Org. Lett. 2013, 15, 3910-3913; c) Z. Zhang, X. Li, M. Song, Y. Wan, D. Zheng, G. Zhang, G. Chen, J. Org. Chem. 2019, 84, 12792-12799; see also ref. 8; For a review on spirocyclic indolines: d) M. J. James, P. O'Brien, R. J. K. Taylor, W. P. Unsworth, Chem. - Eur. J. 2016, 22, 2856-2881.

[22] a) L. Yu, X. Jin, G. Z. Chen, J. Electroanal. Chem. 2013, 688, 371-378; b) M. Tariq, Z. Für Phys. Chem. 2019, O, DOI 10.1515/zpch-2018-1321.

[23] The cis-selectivity for the present dihydroxylation of N-Ts-3-substitutedindoles 1a,e-l is in contrast with our recent electrochemical dimethoxylation of the same substrate 1a that resulted in a trans-selectivity. That may be explained by a hydrogen bond that stabilized the cisisomers of N-Ts-2,3-dihydroxyindolines 9a,e-l. 


\section{UPDATE}

Electrochemical dearomative dihydroxylation and hydroxycyclysation of indoles.

Adv. Synth. Catal. Year, Volume, Page - Page

Ju Wu, Régis Guillot, Cyrille Kouklovsky,
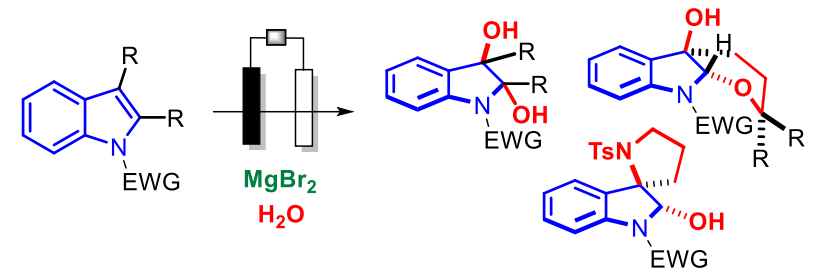

Guillaume Vincent* 